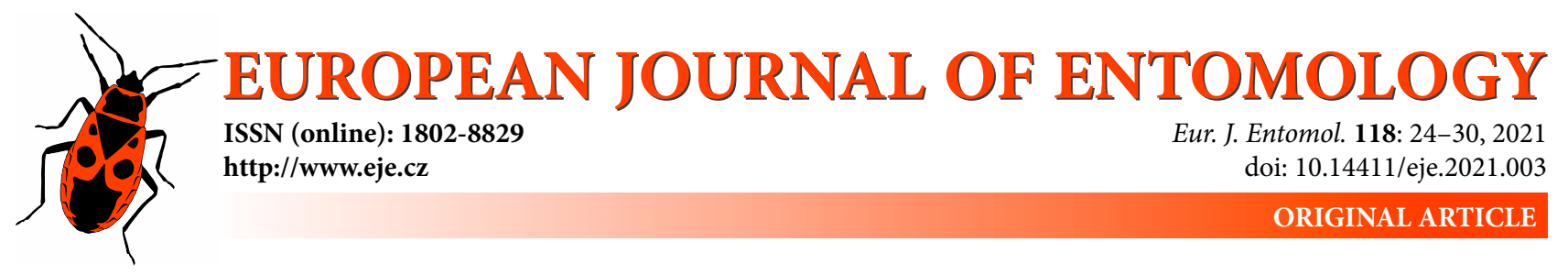

\title{
Invasive brown marmorated stink bug (Hemiptera: Pentatomidae) facilitates feeding of European wasps and ants (Hymenoptera: Vespidae, Formicidae) on plant exudates
}

\author{
DaVide SCACCINI and Alberto POZZEBON \\ Department of Agronomy, Food, Natural Resources, Animals and Environment, University of Padova, Viale dell'Università 16, \\ 35020, Legnaro, Padova, Italy; e-mails: davide.scaccini@phd.unipd.it, alberto.pozzebon@unipd.it \\ ORCID: Davide Scaccini: 0000-0002-6850-7911; Alberto Pozzebon: 0000-0002-2445-7211
}

Key words. Hemiptera, Pentatomidae, Halyomorpha halys, Hymenoptera, Vespidae, Formicidae, facilitative interactions, feeding activity, Fraxinus ornus, invasion ecology, invasive species, native plant exudates, Europe

\begin{abstract}
The brown marmorated stink bug, Halyomorpha halys, is a polyphagous species from eastern Asia, which has spread to America and Europe where it damages many crops. In recently colonized areas, facilitative interactions between $H$. halys and native insects are poorly investigated. In this study, we report for the first time facilitation of native wasp and ant feeding by $H$. halys in Europe. The facilitation was related to the outflow of plant exudates caused by $H$. halys feeding on manna ash trees, where they have aggregated in response to an aggregation pheromone, which then attracted species of Hymenoptera to the infested trees. Trees other than manna ash were not involved in the facilitation between these two taxa. The species that frequently visited infested manna ash were Polistes dominula, Vespa crabro, Formica (Serviformica) cunicularia and Lasius emarginatus, while Polistes cf. nimpha, Vespula germanica, Crematogaster scutellaris and Tapinoma subboreale were occasional visitors. The numbers of wasps and ants feeding on plant exudates differed at different times in a day, with more Hymenoptera foraging in the afternoon, when more $H$. halys individuals were actively feeding. Facilitative interactions, such as those recorded in this study, are important for furthering our understanding of the ecology of invasive species in terms of creating sources of food for native organisms.
\end{abstract}

\section{INTRODUCTION}

When phytophagous stink bugs (Hemiptera: Pentatomidae) feed, they insert their stylets into plant tissue and suck up nutrients, which causes wounding and abortion of fruit and seeds (Panizzi, 1997; Panizzi et al., 2000). Their feeding may affect both the phloem and the xylem of a tree (Torres et al., 2010; Lucini \& Panizzi, 2016).

Brown marmorated stink bug, Halyomorpha halys (Stål), is an invasive species of Pentatomidae native to eastern Asia that was first detected in the United States in the 1990s and Europe in the mid-2000s and now considered one of the most damaging agricultural pests worldwide (Kriticos et al., 2017; Leskey \& Nielsen, 2018). On a wide spectrum of host plants, $H$. halys mainly feeds on phloem (Ghosh et al., 2017), and potentially also on xylem and mesophyll/parenchyma (Serteyn et al., 2020). The damage to crops is usually due to the feeding of both immature and adult stages (Leskey \& Nielsen, 2018). In some crops, $H$. halys infestations can result in an increase in the incidence of plant diseases (e.g. Kamminga et al., 2014; Rice et al., 2014; Paltrinieri et al., 2016; Moore et al., 2019). In the USA, H. halys is reported to feed through the bark of some species of trees, causing the outflow of tree exudates, and this sugary food source was attractive for native species of wasps (Hymenoptera: Vespidae) and ants (Formicidae) (Martinson et al., 2013). Thus, feeding by $H$. halys provides a source of food, facilitating some native species of Hymenoptera, thus making a positive interaction that benefits at least one species and causes harm to neither (sensu Stachowicz, 2001). To our knowledge, facilitative interactions involving plant exudates induced by $H$. halys and native species of insects have not yet been reported in invaded regions other than the USA.

Other examples of facilitation occurring between non native and native species of insects are: the Japanese beetle Popillia japonica Newman (Coleoptera: Scarabaeidae) and the native green June beetle Cotinis nitida (Linnaeus) (Coleoptera: Scarabaeidae) on grapes in the USA (Hammons et al., 2009), and the non native moth Epiblema sugii Kawabe (Lepidoptera: Tortricidae) that induces galls on Ambrosia trifida L. (Asterales: Asteraceae) and native beetles and ants in Japan (Yamazaki \& Sugiura, 2016). Facilitation between invasive and native species, however, is often poorly documented.

Here we report, for the first time in Europe, facilitation of the feeding of native species of Hymenoptera (wasps and 
ants) on manna ash trees by invasive $H$. halys. To study this phenomenon, we artificially induced a long-lasting infestation of $H$. halys in which this pest fed on trunks of trees for months, which resulted in the outflow of plant exudates. We investigated if the presence of wasp and ant foragers was associated with the presence of $H$. halys feeding on trunks of trees and if their abundance differed at different times of day.

\section{MATERIAL AND METHODS}

\section{Site surveyed and methodology}

The experiment was conducted in 2017 at the experimental farm of the Department of Agronomy, Food, Natural resources, Animals and Environment - University of Padua in Legnaro, Padua (north-eastern Italy, $45.344124 \mathrm{~N}, 11.954504$ E, 8 m a.s.1.). On a group of trees of different species (Table 1) all growing close together and located within an area of about $500 \mathrm{~m}^{2}, H$. halys infestations were induced from June until September by using $H$. halys aggregation pheromone lures (Trécé Inc., Adair, OK, USA), which were installed on 5 June 2017. Lures were loaded with a synthetic analog of the aggregation pheromone, i.e. a pheromone that is known to be attractive to both sexes, including nymphs (sensu Millar, 2005) of $H$. halys (Weber et al., 2017). Eight pheromone lures were evenly distributed (every $5 \mathrm{~m}$, maximum three lures per tree; Table 1) by hanging them in the canopies of trees three meters above the ground and renewed every three weeks in the same position. We assessed the abundance of $H$. halys on all the trees in the area every week (5 June -31 August 2017) by beat sampling (beating sheet, $1 \mathrm{~m} \times 1 \mathrm{~m}$, UM01 - Clap Net, Omnes Artes s.a.s., Bergamo, Italy) after 5.30 p.m. In addition, visual inspections of the trunk of each tree were made from 21 July to 31 August 2017 to quantify the number of $H$. halys feeding and the presence of other insects. Trees with pheromone lures were not included in order to avoid bias. Inspections, each lasting $15 \mathrm{~min}$, were carried out at 11:00 a.m., 2:00 p.m. and 5:00 p.m. (GMT +1) local time, every $2-4$ days (13 observation days and 39 surveys in total); surveys were not carried out on rainy days. Immediately before recording the number of wasps and ants present, two minutes were spent counting the number of bark-feeding $H$. halys on each tree. The number of Hymenoptera observed feeding on trunks was recorded on a $1-\mathrm{m}$ section of trunk $1.5 \mathrm{~m}$ from the ground on five randomly selected trees per species. Each 1-m section was inspected, and wasps and ants actively feeding on plant exudates were counted. For ant species, the abundance was ranked in five classes: $0=$ absent, $1=$ less than 10, $2=11-25,3=$ $26-40,4=$ more than 40 workers. Wasp abundance was recorded as absolute numbers. Wasps were identified using Dvořák \& Roberts (2006) and ants initially using a guide (Lebas et al., 2016) followed by confirmation using mtDNA analysis, cytochrome c oxidase subunit I (coxI) as described by Hebert et al. (2003). Additional observations were made in September and October 2017, and in the following two years (not included in statistical analyses).

\section{Statistical analyses}

Data on the abundance of $H$. halys recorded by beat sampling and visual estimates of trunk feeding activity on different species of trees were analyzed using a one-way analysis of variance (ANOVA) through the GLM procedure in SAS (ver. 9.4; SAS Institute, 2016). In this analysis, the number of $H$. halys recorded on different trees by beat sampling and the number observed feeding on the trunks were dependent variables, in two separate analyses in which species of tree were explanatory variables, and their effect was tested using an F test $(\alpha=0.05)$. Differences among tree species were evaluated using a post hoc Tukey's test $(\alpha=0.05)$. Before the analyses, data were checked for ANOVA assumptions and transformed to $\log (\mathrm{x}+1)$.

We assessed the relationship between the numbers of $H$. halys feeding on the trunks of trees and of the most common species of wasps and ants feeding on the associated exudates using linear regression. In this analysis, the mean number of $H$. halys feeding on trunks was the independent variable, and the number of most common species of wasps and ants the dependent variables resulting from the visual inspections of five plants.

The variation in the abundance of $H$. halys and wasps and ants during the course of a day was assessed using the generalized linear mixed model with the MIXED procedure in SAS (ver. 9.4; SAS Institute, 2016). The different times in a day (i.e. 11:00 a.m., 2:00 p.m., and 5:00 p.m.) were the independent variable, while the dependent variables in separate analyses were the number of feeding $H$. halys and the presence of wasps (number of individuals) and ants (classes of abundance) feeding on plant exudates. The effect of the time of day was tested using an F test $(\alpha=0.05)$ followed by post hoc Tukey's test $(\alpha=0.05)$. The factor "tree" (n $=5$ ) was included as a random effect. In this analysis, untransformed data were used.

\section{RESULTS}

In $2017, H$. halys collected by beat sampling was more abundant on Fraxinus ornus L. (Scrophulariales: Oleaceae) than on the other species of trees $\left(\mathrm{F}_{4,320}=619.67, \mathrm{p}<0.001\right.$; Table 1). On the other trees, $H$. halys infestation level was lower on Paulownia tomentosa Steud. (Lamiales: Paulowniaceae) than on Ficus carica L. (Urticales: Moraceae), and the lowest numbers on Juglans regia L. (Juglandales: Juglandaceae) and Olea europaea L. (Scrophulariales: Oleaceae) (Table 1). In addition, the number of $H$. halys recorded feeding on the trunks of $F$. ornus was higher than

Table 1. List of the species of trees at the site studied (listed alphabetically by the order). The abundance of Halyomorpha halys was evaluated by beat sampling (no. of stink bugs per plant; weekly sample from all plants from 5 June to 31 August 2017) and visual records of individuals feeding on the trunks of five randomly chosen plants (from 21 July to 31 August 2017; 13 days, every two to four days). Data are presented as total individuals per plant and per trunk ( \pm st. err.), respectively. Different letters indicate significant differences using Tukey's test $(\alpha=0.05)$.

\begin{tabular}{|c|c|c|c|c|c|c|c|}
\hline Order & Family & Species & $\begin{array}{c}\text { Total no. of } \\
\text { trees (no. with } \\
\text { pheromone lure) }\end{array}$ & $\begin{array}{c}\text { Halyomorpha halys } \\
\text { abundance (mean no./ } \\
\text { plant) }\end{array}$ & & $\begin{array}{l}\text { Halyomorpha halys } \\
\text { feeding individuals/ } \\
\text { trunk }\end{array}$ & \\
\hline Juglandales & Juglandaceae & Juglans regia L. & $6(1)$ & $6.6( \pm 3.0)$ & d & $0.4( \pm 0.2)$ & $\mathrm{b}$ \\
\hline Lamiales & Paulowniaceae & Paulownia tomentosa Steud. & $15(2)$ & $30.2( \pm 2.3)$ & c & $1.2( \pm 0.5)$ & $\mathrm{b}$ \\
\hline Scrophulariales & Oleaceae & $\begin{array}{l}\text { Fraxinus ornus L. } \\
\text { Olea europaea L. }\end{array}$ & $\begin{array}{l}54(3) \\
8(1)\end{array}$ & $\begin{array}{c}1946.0( \pm 94.9) \\
0.8( \pm 0.6)\end{array}$ & $\begin{array}{l}a \\
d\end{array}$ & $\begin{array}{l}51.1( \pm 2.3) \\
0.0( \pm 0.0)\end{array}$ & $\begin{array}{l}a \\
b\end{array}$ \\
\hline Urticales & Moraceae & Ficus carica L. & $7(1)$ & $77.8( \pm 9.2)$ & $b$ & $1.8( \pm 1.0)$ & $\mathrm{b}$ \\
\hline
\end{tabular}



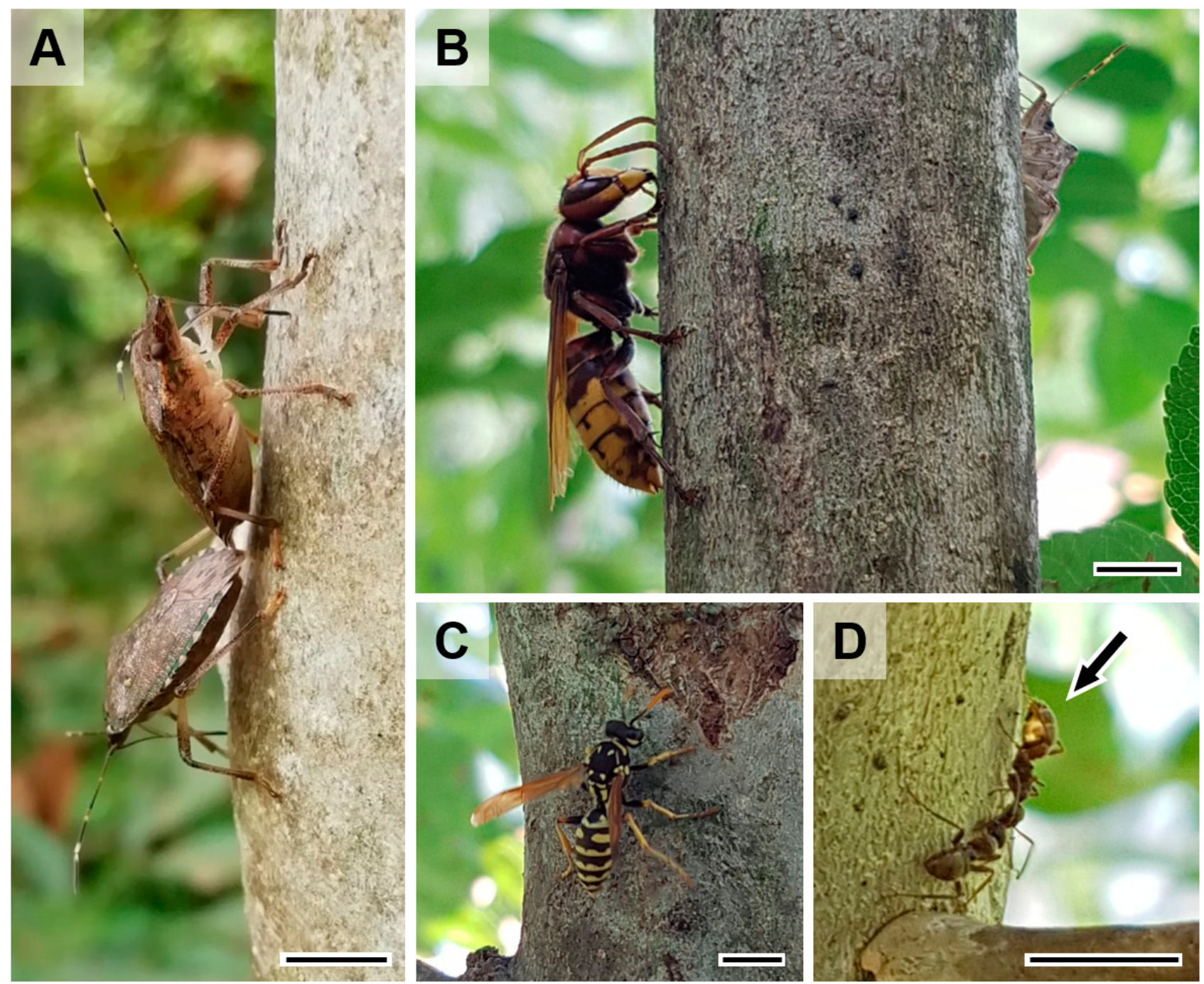

Fig. 1. Halyomorpha halys adults feeding on trunk of Fraxinus ornus (A). The European hornet, Vespa crabro (B) and the paper wasp, Polistes dominula (C) foraging for plant exudates induced by the feeding of $H$. halys. Formica cunicularia workers (D); the arrow indicates the abdomen of a worker containing $F$. ornus exudates. Scale bar: $5 \mathrm{~mm}$.

on other trees $\left(\mathrm{F}_{4.320}=596.43, \mathrm{p}<0.001\right.$; Table 1; Fig. 1A). On F. ornus, their feeding caused the outflow of tree exudates from the feeding wounds, whereas no exudates were detected on other tree species.

Even though some Hymenoptera were recorded on trees other than $F$. ornus, they were not actively feeding on trunks. The European hornet, Vespa crabro Linnaeus (Fig. 1B), the paper wasp Polistes dominula (Christ) (Fig. 1C) and Formica (Serviformica) cunicularia Latreille (Figs 1D and S1B; on all 13 days sampled) regularly visited $F$. ornus trunks to collect exudates. Lasius emarginatus (Olivier) workers were often recorded on $F$. ornus trunks feeding on exudates (on a total of eight days). In August, Polistes cf. nimpha (Christ) and Tapinoma subboreale Seifert were recorded on two and four occasions, respectively. Following this, the results for the most common wasp and ant species that fed on F. ornus (P. dominula, V. crabro, F. cunicularia and L. emarginatus) were analysed statistically.

Abundance of $P$. dominula $\left(\mathrm{F}_{1,193}=16.66, \mathrm{p}<0.001\right.$, $\left.\mathrm{R}^{2}=0.212\right)$ and $F$. cunicularia $\left(\mathrm{F}_{1,193}=12.25, \mathrm{p}<0.001\right.$, $\mathrm{R}^{2}=0.214$ ) actively feeding on $F$. ornus exudates were as- sociated with the presence of bark-feeding $H$. halys. No significant trends were detected between bark-feeding $H$. halys and exudate-feeding foragers of V. crabro $\left(\mathrm{F}_{1,193}=\right.$ $\left.0.60, \mathrm{p}=0.440, \mathrm{R}^{2}=0.140\right)$ or L. emerginatus $\left(\mathrm{F}_{1,193}=\right.$ $0.57, \mathrm{p}=0.450, \mathrm{R}^{2}=0.004$ ).

Foragers of the German yellowjacket, Vespula germanica (Fabricius) (Fig. S1A) were recorded feeding on F. ornus exudates from September to the beginning of October 2017. While all the aforementioned species were recorded in all three years, Crematogaster scutellaris (Olivier) foragers were only recorded feeding on $F$. ornus exudates in 2019 (Fig. S1C).

More individuals of $H$. halys were recorded feeding on the trunks of $F$. ornus in the afternoon than late in the morning $\left(\mathrm{F}_{2,1325}=23.18, \mathrm{p}<0.001\right.$; Fig. 2A). Similarly, more foragers of $P$. dominula $\left(\mathrm{F}_{2,128.1}=40.98, \mathrm{p}<0.001\right.$; Fig. $2 \mathrm{~B})$, V. crabro $\left(\mathrm{F}_{2,48}=120.43, \mathrm{p}<0.001\right)$, F. cunicularia $\left(\mathrm{F}_{2,132.7}=103.55, \mathrm{p}<0.001\right)$ and L. emarginatus $\left(\mathrm{F}_{2,129.4}=\right.$ $21.01, \mathrm{p}<0.001$; Fig. 2C) were recorded feeding on plant exudates in the afternoon than in the morning. Vespa crabro was never observed in the morning, and more individu- 
A

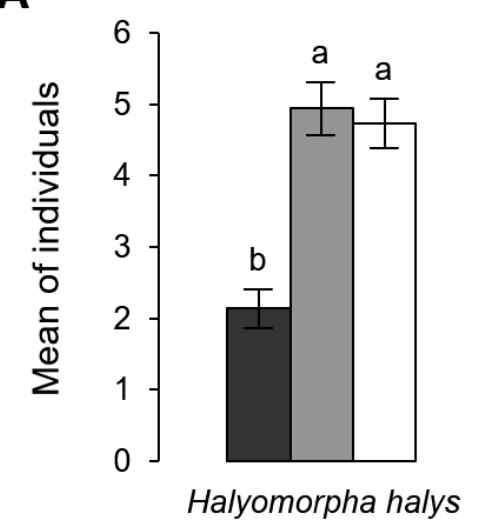

B

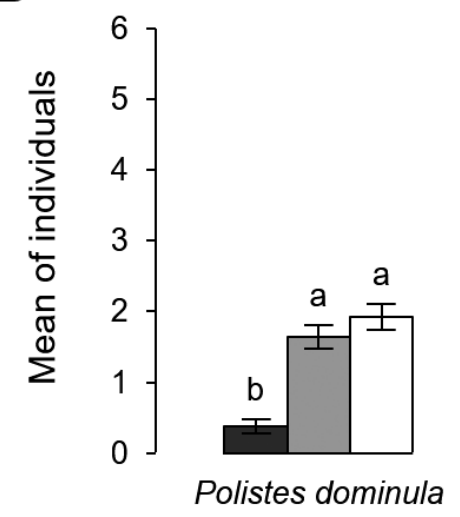

C

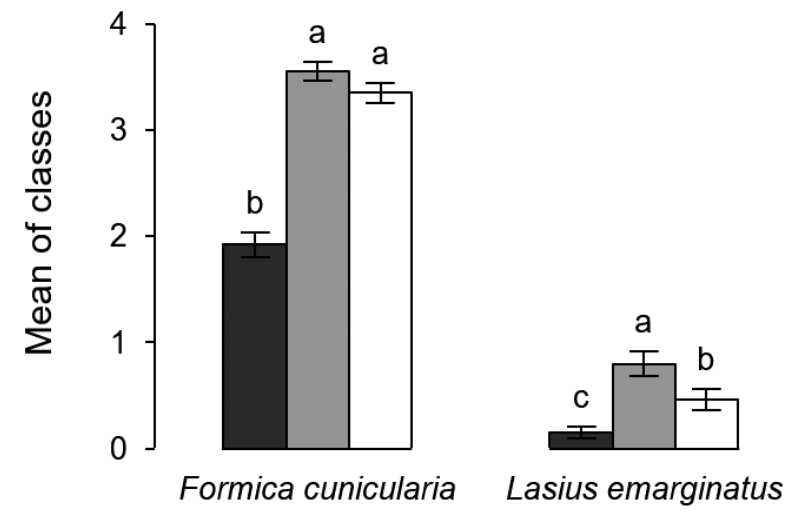

Fig. 2. Presence of Halyomorpha halys, wasps and ants feeding on Fraxinus ornus trunks at different times of a day (from 21 July to 31 August 2017). Halyomorpha halys (A). Polistes dominula and Vespa crabro (B). Formica cunicularia and Lasius emarginatus (C; for ant species, abundance classes are: $0=$ absent, $1=$ less than $10,2=11-25,3=26-40,4=$ more than 40 workers). Bars indicate standard errors. Different letters indicate significant differences based on Tukey's test $(\alpha=0.05)$.

als visited $F$. ornus trunks at 5:00 p.m. than at 2:00 p.m. (Fig. 2B). In contrast, L. emarginatus foragers were more abundant at 2:00 p.m. than at 5:00 p.m., and at 11:00 a.m. they were less abundant than at other times (Fig. 2C).

Furthermore, $P$. dominula, $V$. crabro and $V$. germanica were recorded disturbing and removing $H$. halys in order to collect fresh exudates from the trunk (Fig. S2), but this aggressive behaviour was only recorded on a few occasions.

\section{DISCUSSION}

Here we report, for the first time in Europe, facilitation of native wasp and ant feeding by invasive $H$. halys. These interactions are associated with the outflow of exudates from feeding punctures of $H$. halys on the trunks of $F$. ornus. In the USA, Fraxinus americana L. is considered to be an important host plant of stink bugs and hosts high densities of H. halys (Nielsen \& Hamilton, 2009). Feeding on trunks or twigs is uncommon in stink bugs (Panizzi, 1997), but is reported for $H$. halys in the USA by Martinson et al. (2013) and also confirmed in Europe.

In the area studied, the induced-massive feeding on the trunks of manna ash trees by $H$. halys resulted in exudate outflow from their feeding punctures, which attracted eight species of native wasps and ants. No wasps or ants, however, were observed feeding on the liquid faeces produced by $H$. halys. Despite $H$. halys fed on species of trees other than $F$. ornus, we did not observe exudate outflow from the feeding punctures, possibly due to specific features of those trees and the low stink bug numbers recorded feeding on them. In this study, high infestation levels were artificially induced by using pheromone lures, so that the results do not reflect the true extent of the interaction between $H$. halys and other insects brought about by their feeding on the trunks of manna ash. Outbreaks of $H$. halys, however, are reported in invaded areas in Europe (e.g. Costi et al., 2017; Leskey \& Nielsen, 2018; Maistrello et al., 2018). In addition, bark-feeding by $H$. halys is reported at other sites where attraction of $V$. germanica and Formica sp. on $F$. ornus and, with a less extent, on Acer sp. exudates following natural outbreaks of $H$. halys was observed in 2017 and 2019 (D. Scaccini, unpubl.). These observations indicate that facilitation of European wasp and ant feeding by $H$. halys may occur naturally in other areas. Similarly, the interactions between $H$. halys and native Hymenoptera reported in Maryland and West Virginia indicate that at least five species of native wasps and ants and two cosmopolitan ants are attracted by the carbohydrate rich source exuding from the feeding wounds made by this stink bug (Martinson et al., 2013).

Nutrient requirements of wasps and ants include carbohydrates, usually obtained from (extra)floral nectaries, honeydew, fruit, plant sap and other products, as well as anthropogenic compounds. Sugars are used as an energy source by wasps (Raveret Richter, 2000) and in metabolism and sperm production by ants (Wäckers et al., 2005; Blüthgen \& Feldhaar, 2010).

Phloem sap is a food rich in sugars (Douglas, 2006) and, as reported for Oleaceae in general (Wäckers et al., 2005), Fraxinus exudates contain mannitol, fructose, glucose and other monosaccharides, together with oligosaccharides such as mannotriose and stachyose (Caligiani et al., 2013). Vespa crabro is known to feed on tree sap (Yoshimoto \& Nishida, 2009) and Archer (2014) states that V. crabro actively wounds twigs of ash and lilac trees in order to cause an outflow of sap. Ants foraging activity on manna ash tree exudates is not surprising because sugar is a common part of the diet of Formicinae such as F. cunicularia (Akyürek 
et al., 2016; Novgorodova \& Ryabinin, 2018) and Lasius species (Madsen et al., 2017), in which the workers have receptors that possibly perceive carbohydrates (Tinti \& Nofre, 2001). Crematogaster scutellaris is omnivorous and may attack and eat $H$. halys (Castracani et al., 2017), but in this study, it was only recorded foraging for plant exudates.

Halyomorpha halys feeding activity varied during the course of a day being higher in the afternoon than late in the morning. Indeed, $H$. halys activity increases with increase in temperature, but probing activity stops above 26.5-29.6 ${ }^{\circ} \mathrm{C}$ (Wiman et al., 2014), development ceases at $35^{\circ} \mathrm{C}$ and it dies at higher temperatures (Haye et al., 2014; Aigner \& Kuhar, 2016; Scaccini et al., 2019).

More wasps and ants were recorded feeding on $F$. ornus exudates in the afternoon than in the morning. Indeed, when it is warm, the rate of delivery of sugars by wasp foragers to their nest is higher than at lower temperatures, as reported for $V$. germanica (Jandt et al., 2010). Similarly, ant foraging activity is affected by environmental factors such as temperature, light intensity and other physical and biotic factors (Traniello, 1989), and at least in boreal forests, it generally increases in warm periods (Domisch et al., 2009).

Furthermore, on manna ash trees Vespidae disturbed $H$. halys feeding on the trunks. In fact, the aggressive behaviour of wasps toward other insects feeding on plant exudates was quoted by Wilson (1926) and, more recently, by Yoshimoto \& Nishida (2009) and it dominates the hierarchies of insects feeding on plant exudates. Further investigations on aggressive behaviour, however, are needed for a better understanding of the plant exudate-feeding insect community.

The outflow of plant exudates that result from the feeding of phytophagous insects is known to attract different species of Hymenoptera in other regions (Yamazaki, 2007; Martinson et al., 2013), hence considered herbivores under an ecological point of view (Jones, 1994; Raveret Richter, 2000; Yoshimoto \& Nishida, 2009; Iakovlev et al., 2017). Non native species can increase the availability of this sugary food source and create a novel feeding niche for native organisms (Rodriguez, 2006) that feed on tree exudates induced by phytophagous species. The positive interactions reported here are important for further understanding the ecology of invasive non native organisms, which induce plants to liberate exudates that are as attractive for native Hymenoptera as other sources of sugar from plants.

ACKNOWLEDGEMENTS. We are grateful to I. Martinez-Sañudo for help with the DNA analysis. We would like to thank A. Battisti and M. Uemura for careful revisions and suggestions, which improved the quality of the manuscript. Thanks to D. Corcos, F. Giomi, M. Marchioro, P. Tirello and L. Tonina for their assistance.

\section{REFERENCES}

Aigner J.D. \& KuHAR T.P. 2016: Lethal high temperature extremes of the brown marmorated stink bug (Hemiptera: Pentatomidae) and efficacy of commercial heat treatments for control in expert shipping cargo. - J. Agric. Urban Entomol. 32: 1-6.

AKyÜReK B., ZeYbeKoĞLu Ü., GÖRÜr G. \& Karavin M. 2016: Reported aphid (Hemiptera: Aphidoidea) and ant (Hymenoptera:
Formicidae) species associations from Samsun Province. - J. Entomol. Res. Soc. 18: 97-106.

Archer M.E. 2014: The Vespoid Wasps (Tiphiidae, Mutillidae, Sapygidae, Scoliidae and Vespidae) of the British Isles. Royal Entomological Society, St. Albans, vi +82 pp.

Blüthgen N. \& FeldhaAR H. 2010: Food and shelter: How resources influence ant ecology. In Lach L., Parr C.L. \& Abbott K.L. (eds): Ant Ecology. Oxford University Press, Oxford, pp. 115-136.

Caligiani A., Tonelli L., Palla G., Marseglia A., Rossi D. \& BRUNI R. 2013: Looking beyond sugars: Phytochemical profiling and standardization of manna exudates from Sicilian Fraxinus excelsior L. - Fitoterapia 90: 65-72.

Castracani C., Bulgarini G., Giannetti D., Spotti F.A., Maistrello L., Mori A. \& Grasso D.A. 2017: Predatory ability of the ant Crematogaster scutellaris on the brown marmorated stink bug Halyomorpha halys. - J. Pest Sci. 90: 1181-1190.

Costi E., Haye T. \& Maistrello L. 2017: Biological parameters of the invasive brown marmorated stink bug, Halyomorpha halys, in southern Europe. - J. Pest Sci. 90: 1059-1067.

Domisch T., Finér L., Neuvonen S., Niemelä P., Risch A.C., Kilpeläinen J., Ohashi M. \& Jurgensen M.F. 2009: Foraging activity and dietary spectrum of wood ants (Formica rufa group) and their role in nutrient fluxes in boreal forests. Ecol. Entomol. 34: 369-377.

Douglas A.E. 2006: Phloem-sap feeding by animals: Problems and solutions. - J. Exp. Bot. 57: 747-754.

Dvoř́́K L. \& RoBerTs S.P.M. 2006: Key to the paper and social wasps of Central Europe (Hymenoptera: Vespidae). - Acta Entomol. Mus. Nat. Prag. 46: 221-244.

Ghosh S.K.B., Hunter W.B., Park A.L. \& Gundersen-Rindal D.E. 2017: Double strand RNA delivery system for plant-sapfeeding insects. - PLoS ONE 12: e0171861, 19 pp.

Hammons D.L., Kurtural S.K., Newman M.C. \& Potter D.A. 2009: Invasive Japanese beetles facilitate aggregation and injury by a native scarab pest of ripening fruits. - Proc. Natl. Acad. Sci. USA 106: 3686-3691.

Haye T., Abdallah S., Gariepy T. \& Wyniger D. 2014: Phenology, life table analysis and temperature requirements of the invasive brown marmorated stink bug, Halyomorpha halys, in Europe. - J. Pest Sci. 87: 407-418.

Hebert P.D.N., Cywinska A., Ball S.L. \& DeWaARd J.R. 2003: Biological identifications through DNA barcodes. - Proc. Roy. Soc. (B) 270: 313-321.

Iakovlev I.K., Novgorodova T.A., Tiunov A.V. \& Reznikova Z.I. 2017: Trophic position and seasonal changes in the diet of the red wood ant Formica aquilonia as indicated by stable isotope analysis. - Ecol. Entomol. 42: 263-272.

JANDT J.M., TAYLOR B. \& JEANNE R.L. 2010: Temperature and forager body size affect carbohydrate collection in German yellowjackets, Vespula germanica (Hymenoptera, Vespidae). Insect. Soc. 57: 275-283.

JONES R.A. 1994: Ants feeding directly on plant sap. - Brit. J. Entomol. Nat. Hist. 7: 139-140.

Kamminga K., Herbert D.A., Toews M.D., Malone S. \& Kuhar T. 2014: Halyomorpha halys (Hemiptera: Pentatomidae) feeding injury on cotton bolls. - J. Cotton Sci. 18: 68-74.

Kriticos D.J., Kean J.M., Phillips C.B., Senay S.D., Acosta H. \& HAYE T. 2017: The potential global distribution of the brown marmorated stink bug, Halyomorpha halys, a critical threat to plant biosecurity. - J. Pest Sci. 90: 1033-1043.

Lebas C., Galkowski C., Blatrix R. \& Wegnez P. 2016: Fourmis d'Europe Occidentale. Delachaux et Niestlé, Paris, 415 pp.

LESKEy T.C. \& Nielsen A.L. 2018: Impact of the invasive brown marmorated stink bug in North America and Europe: History, 
biology, ecology, and management. - Annu. Rev. Entomol. 63 599-618.

LuCINI T. \& PANIZZI A.R. 2016: Waveform characterization of the soybean stem feeder Edessa meditabunda: Overcoming the challenge of wiring pentatomids for EPG. - Entomol. Exp. Appl. 158: 118-132.

Madsen N.E.L., Sørensen P.B. \& Offenberg J. 2017: Sugar and amino acid preference in the black garden ant Lasius niger (L.). - J. Insect Physiol. 100: 140-145.

Maistrello L., Dioli P., Dutto M., Volani S., Pasquali S. \& GiLIoli G. 2018: Tracking the spread of sneaking aliens by integrating crowdsourcing and spatial modeling: The Italian invasion of Halyomorpha halys. - BioScience 68: 979-989.

Martinson H.M., Raupp M.J. \& Shrewsbury P.M. 2013: Invasive stink bug wounds trees, liberates sugars, and facilitates native Hymenoptera. — Ann. Entomol. Soc. Am. 106: 47-52.

Millar J.C. 2005: Pheromones of True Bugs. In Schulz S. (ed.): The Chemistry of Pheromones and Other Semiochemicals II. Topics in Current Chemistry, Vol. 240. Springer, Berlin, Heidelberg, pp. 37-84.

Moore L.C., Tirello P., Scaccini D., Toews M.D., Duso C. \& Pozzebon A. 2019: Characterizing damage potential of the brown marmorated stink bug (Hemiptera: Pentatomidae) in cherry orchards. - Entomol. Gen. 39: 271-283.

Nielsen A.L. \& Hamilton G.C. 2009: Life history of the invasive species Halyomorpha halys (Hemiptera: Pentatomidae) in Northeastern United States. - Ann. Entomol. Soc. Am. 102: 608-616.

Novgorodova T.A. \& Ryabinin A.S. 2018: Ant-aphid relations in the south of Western Siberia (Hymenoptera: Formicidae; Hemiptera: Aphididae). - Arthropod-Plant Inter. 12: 369-376.

Paltrinieri S., Marani G., Francati S., Dindo M.L. \& Bertaccin A. 2016: Cimice asiatica confermata come insetto vettore di fitoplasmi. - Informat. Agrar. 45: 60-61.

PANIZZI A.R. 1997: Wild hosts of pentatomids: Ecological significance and role in their pest status on crops. - Annu. Rev. Entomol. 42: 99-122.

Panizzi A.R., McPherson J.E., James D.G., JaVAhery M. \& McPherson R.M. 2000: Stink bugs (Pentatomidae). In Schaefer C.V. \& Panizzi A.R. (eds): Heteroptera of Economic Importance. CRC, New York, pp. 421-474.

RAVERET Richter M. 2000: Social wasp (Hymenoptera: Vespidae) foraging behavior. - Annu. Rev. Entomol. 45: 121-150.

Rice K.B., Bergh C.J., Bergmann E.J., Biddinger D.J., Dieckhoff C., Dively G., Fraser H., Gariepy T., Hamilton G., Haye T. et al. 2014: Biology, ecology, and management of brown marmorated stink bug (Hemiptera: Pentatomidae). $-J$. Integr. Pest Manag. 5: 1-13.
RodrigUEz L.F. 2006: Can invasive species facilitate native species? Evidence of how, when, and why these impacts occur. Biol. Invas. 8: 927-939.

SAS InstituTe 2016: PROC User's Manual, 6th ed. SAS Institute, Cary, NC. URL: http://support.sas.com/documentation/cdl/en/ indbug/68442/PDF/default/indbug.pdf (last accessed 11 April 2020).

Scaccini D., Duso C. \& Pozzebon A., 2019: Lethal effects of high temperatures on brown marmorated stink bug adults before and after overwintering. - Insects 10: 355, $11 \mathrm{pp.}$

Serteyn L., Ponnet L., Backus E.A. \& Francis F. 2020: Characterization of electropenetrography waveforms for the invasive heteropteran pest, Halyomorpha halys, on Vicia faba leaves. Arthropod-Plant Inter. 14: 113-126.

STACHOWICZ J.J. 2001: Mutualism, facilitation, and the structure of ecological communities. - BioScience 51: 235-246.

TinTI J.-M. \& Nofre C. 2001: Responses of the ant Lasius niger to various compounds perceived as sweet in humans: A structure-activity relationship study. - Chem. Senses 26: 231-237.

Torres J.B., Barros E.M., Coelho R.R. \& Pimentel R.M.M. 2010: Zoophytophagous pentatomids feeding on plants and implications for biological control. - Arthropod-Plant Inter. 4: 219-227.

Traniello J. 1989: Foraging strategies of ants. - Annu. Rev. Entomol. 34: 191-210.

WÄCKeRs F.L., vAN RIJN P.C.J. \& BRUIN J. 2005: Plant-Provided Food for Carnivorous Insects: A Protective Mutualism and its Applications. Cambridge University Press, New York, 356 pp.

Weber D.C., Morrison W.R., Khrimian A., Rice K.B., Leskey T.C., Rodriguez-Saona C., Nielsen A.L. \& Blaauw B.R. 2017: Chemical ecology of Halyomorpha halys: discoveries and applications. - J. Pest Sci. 90: 989-1008.

WILSON G.F. 1926: Insect visitors to sap-exudations of trees. Trans. Entomol. Soc. Lond. 74: 243-254 + pl. LXV-LXVII.

Wiman N.G., Walton V.M., Shearer P.W. \& Rondon S.I. 2014: Electronically monitored labial dabbing and stylet 'probing' behaviors of brown marmorated stink bug, Halyomorpha halys, in simulated environments. - PLOS ONE 9: e113514, 24 pp.

YAMAZAKI K. 2007: Cicadas "dig wells" that are used by ants, wasps and beetles. - Eur. J. Entomol. 104: 347-349.

YAMAZAKI K. \& SUgIURA S. 2016: Stem-galling moths provide cetoniine beetles with feeding sites via sap exudation of invasive alien plants. - Entomol. Sci. 19: 142-146.

Yosнiмото J. \& Nishida T. 2009: Factors affecting behavioral interactions among sap-attracted insects. - Ann. Entomol. Soc. Am. 102: 201-209.

Received June 2, 2020; revised and accepted December 30, 2020 Published online February 5, 2021

Supplementary Figs S1-S2 follow on next page. 

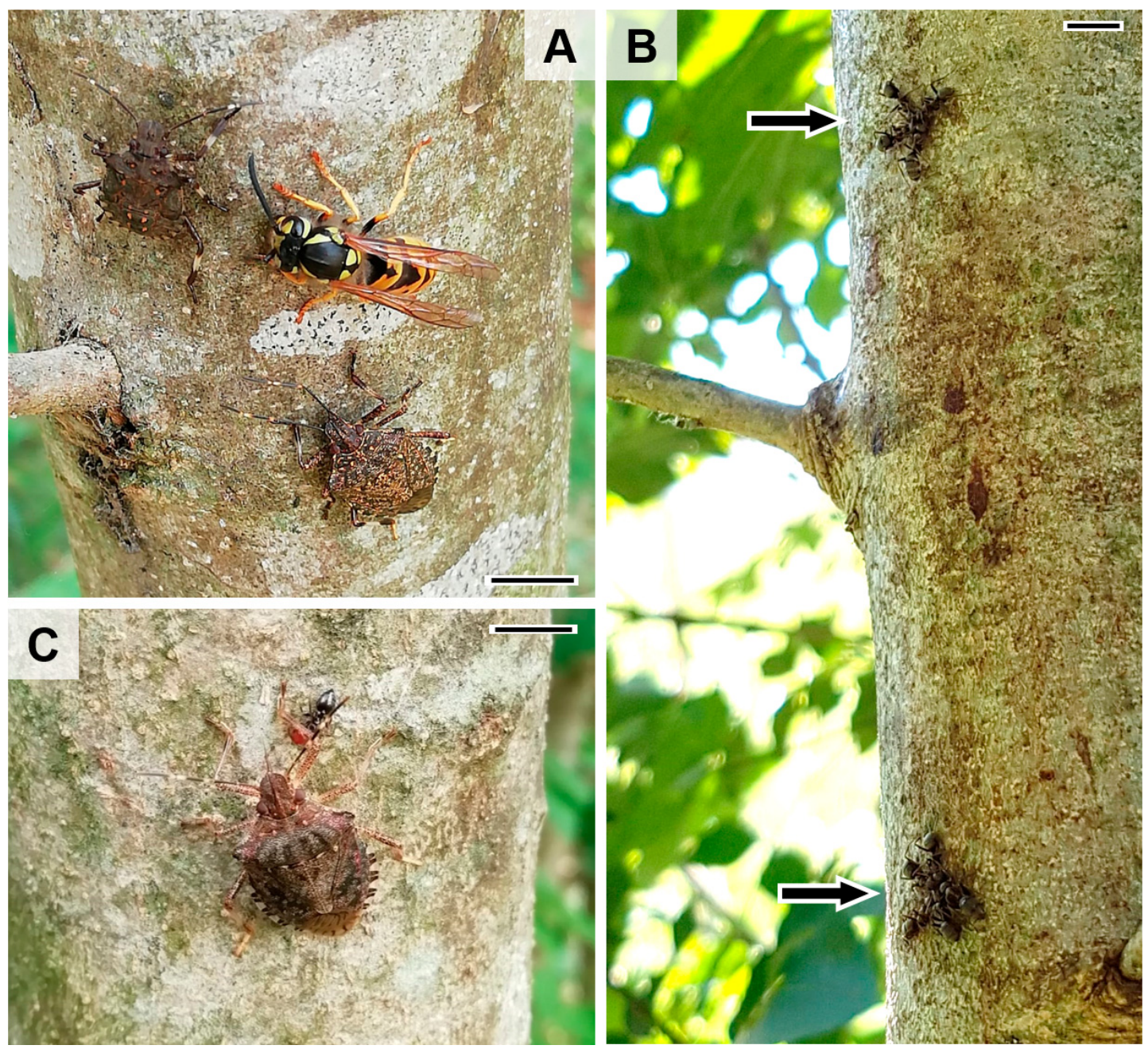

Fig. S1. Vespula germanica foraging for Fraxinus ornus exudates, with two Halyomorpha halys individuals (A). Formica cunicularia workers (indicated by arrows) grouped on plant exudates in the afternoon (B). A worker of Crematogaster scutellaris foraging for exudates, with a $H$. halys adult $(C)$. Scale bar: $5 \mathrm{~mm}$.
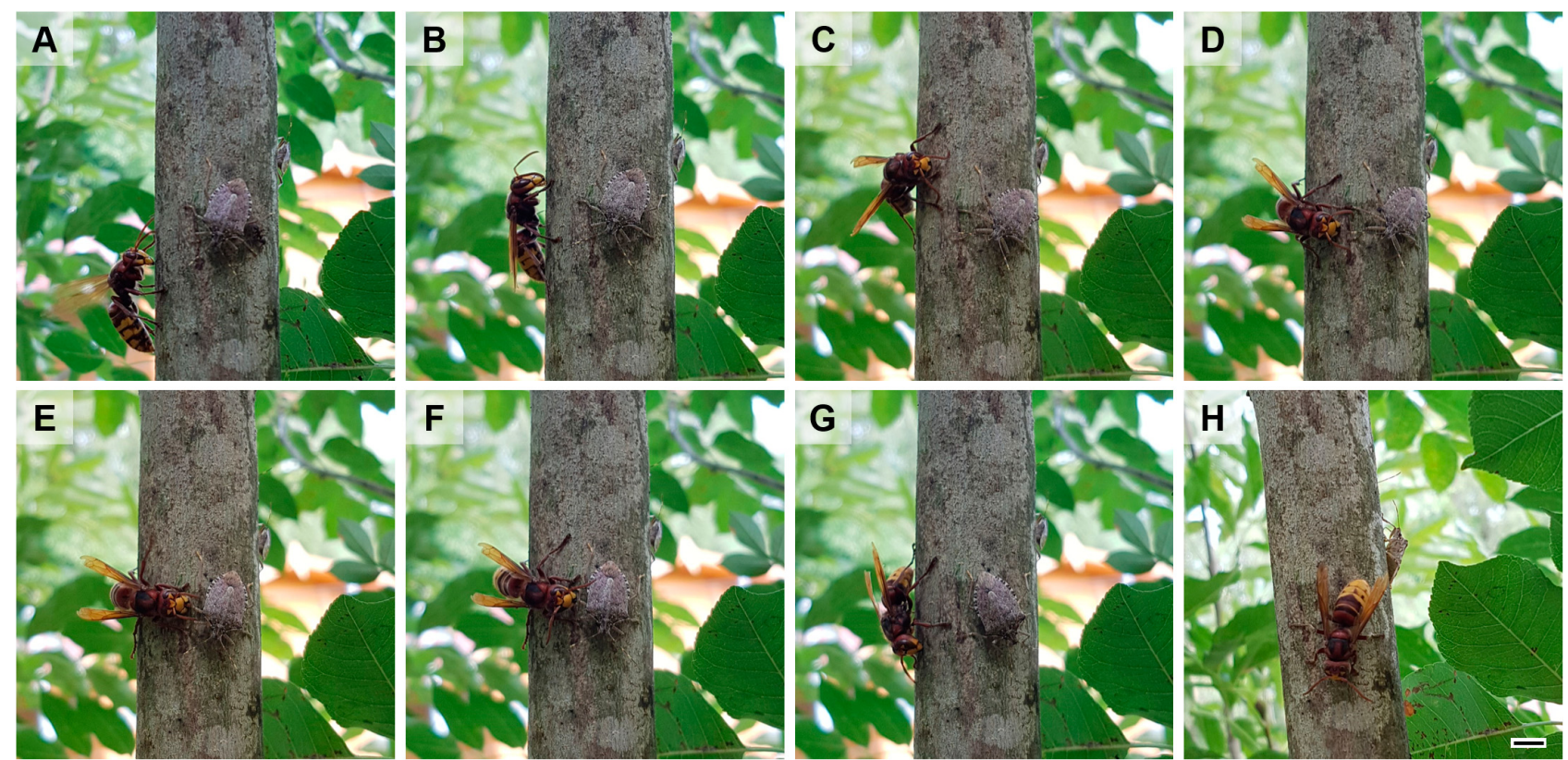

Fig. S2. Sequence of pictures of Vespa crabro disturbing and driving away Halyomorpha halys feeding on the trunk of Fraxinus ornus. European hornet landing on the trunk of manna ash close to an adult of $H$. halys (A) and searching for plant exudates (B). Movement to the adult $H$. halys (C). First approach to $H$. halys (D) followed by biting its leg (E, F). Movement of the $H$. halys disturbed by the hornet (G). Hornet searching for plant exudates in the area where $H$. halys was feeding $(H)$. Scale bar: $5 \mathrm{~mm}$. 